
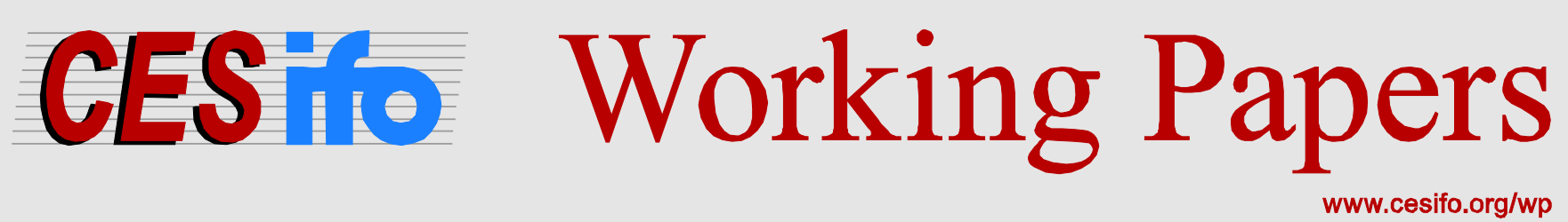

\title{
Anti Profit-Shifting Rules and Foreign Direct Investment
}

\author{
Thiess Buettner \\ Michael Overesch \\ Georg Wamser
}

CESIFO WORKING PAPER NO. 4710

CATEgory 1: PuBliC FinANCE

MARCH 2014

An electronic version of the paper may be downloaded

- from the SSRN website:

- from the RePEc website:

- from the CESifo website:

WWW.SSRN.com

www.RePEc.org

www.CESifo-group.org/wp

\section{CESifo}




\title{
Anti Profit-Shifting Rules and Foreign Direct Investment
}

\begin{abstract}
This paper explores the effects of tax provisions aimed at restricting multinationals' tax planning on foreign direct investment (FDI). Using a unique dataset which allows us to observe the worldwide activities of a large panel of multinational firms, we test how limitations of interest tax deductibility, so-called thin-capitalization rules, and regulations of transfer pricing by the host country affect investment and employment of foreign subsidiaries. The results indicate that, compared with the unrestricted case, in the presence of a typical thin-capitalization rule, the tax-rate sensitivity of FDI is about twice as large. Moreover, introducing such a rule or making it more tight exerts significant adverse effects on the level of FDI in high-tax countries. Regulations of transfer pricing, however, are not found to exert significant effects on FDI.
\end{abstract}

JEL-Code: H250, F230.

Keywords: FDI, corporate taxation, tax competition, profit shifting, thin-capitalization rules, transfer-pricing regulations, affiliate-level data, foreign subsidiary, employment.

Thiess Buettner

University of Erlangen-Nuremberg

Lange Gasse 20

Germany - 90403 Nuremberg

thiess.buettner@fau.de

\author{
Michael Overesch \\ University of Cologne \\ Albertus-Magnus Platz \\ Germany - 50923 Cologne \\ overesch@wiso.uni-koeln.de
}

\author{
Georg Wamser \\ University of Tuebingen \\ Mohlstr. 36 \\ Germany-72074 Tuebingen \\ georg.wamser@uni-tuebingen.de
}

January 2014 


\section{Introduction}

The international consensus on the taxation of multinational corporations (MNCs) subjects the profits of each foreign subsidiary to corporate income taxation in the host country. Taxable profits are determined by separate accounting for each subsidiary. In this setting, international tax-rate differences provide an incentive to alter the profit allocation between the parent company and all subsidiaries of an MNC. This tax planning has adverse consequences for tax revenues in high-tax countries, and enhanced opportunities to reduce taxes may give multinationals an advantage over companies operating only at a domestic level (Bucovetsky and Haufler, 2008). As a consequence, tax policy is under pressure to restrict multinational tax planning.

Countries hosting foreign firms have responded by unilaterally introducing specific anti profitshifting rules, i.e., rules that restrict the foreign subsidiaries' ability to shift profits abroad. Starting with initiatives by the European Commission (1997) and by the OECD (1998) and with the more recent OECD (2013) initiative to restrain 'tax base erosion and profit shifting' (BEPS), also supranational organizations have suggested to implement measures that restrict multinationals tax-planning opportunities.

Despite unilateral implementation and international initiatives, it is not clear whether such restrictions are generally beneficial for the imposing countries. The theoretical literature on profit shifting has emphasized that opportunities for tax planning might help to establish a preferential tax regime that has positive implications for tax revenues in a context of tax competition (e.g., Keen, 2001; Janeba and Smart, 2003; Peralta, Wauthy and van Ypersele, 2006; Bucovetsky and Haufler, 2008, Becker and Fuest, 2012). A similar argument has been discussed in the theoretical 
literature on the role of tax havens in tax competition (e.g., Slemrod and Wilson, 2008, Hong and Smart, 2010; Haufler and Runkel, 2012). From this perspective, profit-shifting restrictions may exert adverse effects on foreign direct investment and may raise the sensitivity of foreign direct investment with respect to the host-country's corporation tax rate. However, empirical evidence on these predictions is lacking.

Against this background, this paper analyzes empirically the effects of anti profit-shifting provisions on foreign direct investment. The analysis employs a unique micro-level database made available by the German central bank (Deutsche Bundesbank), which provides information on virtually all foreign subsidiaries of German multinational firms. We use this data in combination with information on anti profit-shifting rules enacted by the host countries of foreign subsidiaries in 39 countries over 12 years and examine whether and to what extent these measures affect foreign direct investment of multinational firms.

The empirical analysis focuses on anti profit-shifting measures directed against internal debt financing and transfer pricing, which have been identified as key mechanisms for profit shifting in the recent literature. With regard to internal debt financing, subsidiaries of multinational firms located in high-tax countries tend to borrow from entities located in low-tax countries (Desai, Foley, and Hines, 2004; Huizinga, Laeven and Nicodème, 2008; Buettner and Wamser, 2013). This enables multinationals to save taxes since the taxes avoided through the interest deduction at the high-tax location exceed the taxes on interest income at the low-tax location. There is also evidence that firms adjust prices for intrafirm trade, so called transfer prices, to lower the tax base in high-tax countries (e.g., Swenson, 2001; Bartelsman and Beetsma, 2003; Clausing, 2003). The extent to which this is possible, however, varies across industries, and intrafirm transactions related to roy- 
alty payments, $R \& D$, intangible assets, or advertising are found to be particularly tax-sensitive (Harris, 1993; Grubert, 2003; Dischinger and Riedel, 2011).

With regard to the two main methods of profit shifting, host countries have implemented measures aimed at restricting profit shifting through so-called thin-capitalization rules and through rules limiting the scope for manipulation of transfer prices. $^{1}$ Previous studies have demonstrated that thin-capitalization rules have significant effects on financial decisions of firms. Buettner, Overesch, Schreiber, and Wamser (2012) examine how thin-capitalization rules affect debt financing of firms in 36 countries. They find that stricter rules reduce parent and related party debt, but also provide evidence for a substitution with unrestricted forms of debt finance. ${ }^{2}$ The literature also supports the effectiveness of transfer pricing regulations (Beuselinck, Deloof and Vanstraelen, 2009, and Jost, Pfaffermayer and Winner, 2010). However, the implications for foreign direct investment of both thin-capitalization rules and transfer-pricing regulations depend not only on their effectiveness. On the one hand, given the many dimensions along which multinational corporations can structure their worldwide activities, other tax planning schemes might help to circumvent effective restrictions. The availability of such options also depends on the responses of other countries. On the other hand, imposing restrictions might nevertheless exert strong effects if investors regard such restrictions as a signal that future taxes will stay high or increase (Mintz and Weichenrieder, 2010, p.164).

Our empirical results show that anti profit-shifting legislation intensifies the adverse tax effects on

\footnotetext{
${ }^{1}$ While our focus is on tax-law provisions that aim at preventing subsidiaries of foreign multinationals to shift the profits abroad, it should be noted that also the tax-law provisions in the home country of the multinational, i.e. the parent country, may interact with host-country rules. However, since our analysis is concerned with multinationals that share the same parent country, this issue is not explored in this paper.

${ }^{2}$ Evidence for the German thin-capitalization rule is provided by Weichenrieder and Windischbauer (2008), Overesch and Wamser (2010), as well as Wamser (2013).
} 
foreign direct investment. In particular, we find that thin-capitalization rules are associated with a stronger response of foreign direct investment to a tax-rate increase. Our results also indicate that imposing thin-capitalization restrictions is accompanied with adverse effects on employment and investment by multinational companies in host countries with rather high tax rates. Transferpricing regulations, however, are not found to exert significant effects.

The paper is organized as follows. Section 2 explains basic features of anti profit-shifting measures, discusses their likely consequences for FDI and considers some empirical indicators of these measures. Section 3 provides information on the data and the investigation approach. Section 4 presents and interprets our empirical results on the effects of anti profit-shifting measures on foreign subsidiaries' investment. Section 5 presents results of robustness checks that use alternative specifications and employment as an alternative indicator of foreign direct investment. Section 6 concludes.

\section{Anti Profit-Shifting Rules}

Faced with MNCs' tax planning through debt financing as well as transfer pricing of intrafirm trade, many governments of countries hosting foreign firms have introduced specific anti profit-shifting rules, i.e., tax provisions aimed at restricting the foreign subsidiaries' ability to shift profits by means of debt financing and transfer pricing. In the following, we consider each of these rules, separately. 


\subsection{Thin-Capitalization Rules}

MNCs can use the financial structure of foreign operations in order to alter the international allocation of taxable profits. In particular, intercompany debt financing can be used to create interest payments that are deducted in high-tax countries and subject to tax in low-tax countries. Therefore, international tax-rate differentials give rise to thinly-capitalized subsidiaries of multinationals in high-tax countries. From a theoretical point of view, a multinational firm operating an internal capital market can minimize its overall tax payments by lending from the affiliate facing the lowest tax within the firm to all other subsidiaries (see Mintz and Smart, 2004).

As a consequence, some host countries of foreign subsidiaries, especially those that impose high taxes, have responded by introducing so-called thin-capitalization rules. ${ }^{3}$ These rules usually restrict the interest deduction for loans from related parties such as the parent or some other foreign affiliate. ${ }^{4}$ More specifically, if a firm's debt in proportion to its equity capital is above a certain threshold level, interest deduction for related party loans is limited. ${ }^{5}$ The threshold level of debt is commonly referred to as the safe haven debt-to-equity ratio (OECD, 1987), indicating that only with a lower debt-to-equity ratio interest deduction is safely granted by the host-country's tax system.

\footnotetext{
${ }^{3}$ While we focus on formal thin-capitalization rules, it should be noted that a country may also restrict excessive interest deduction by means of a general substance over form rule, although it has no explicit thin-capitalization rule.

${ }^{4}$ See also the International Fiscal Association's report on thin capitalization, which provides an overview of thincapitalization rules in 29 countries (Piltz, 1996). More recent overviews about thin-capitalization rules in Europe are provided by Ambrosanio and Caroppo (2005) and Dourado and de la Feria (2008).

${ }^{5}$ While thin-capitalization rules tend to identify profit-shifting using the level of debt, firms might resort to setting high interest rates at low debt levels. However, this would tend to conflict with the arm's length principle and only offers limited leeway for profit shifting (Piltz, 1996: 103p).
} 
Figure 1: Increasing Usage of Thin-Capitalization Rules among OECD Countries

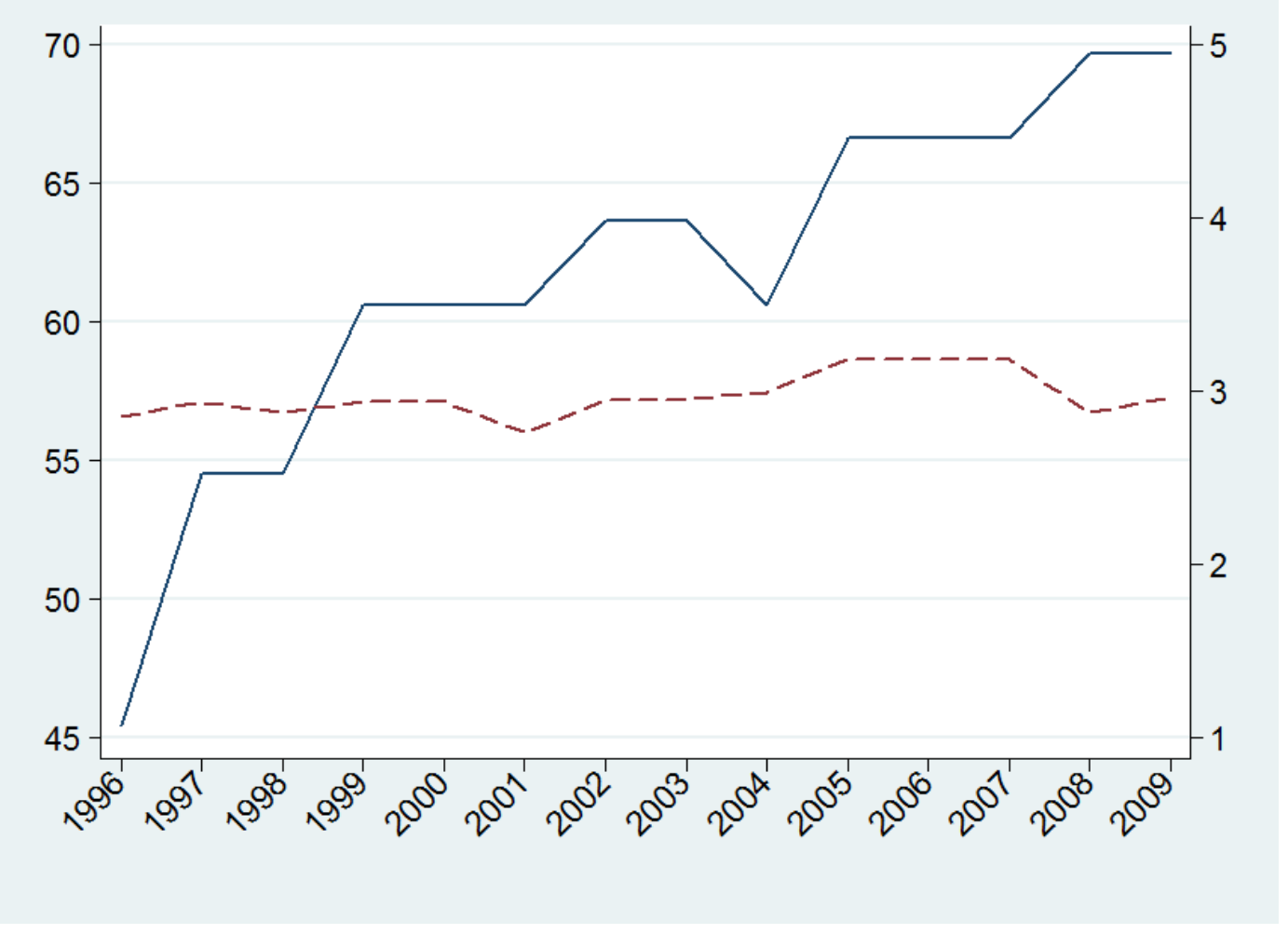

Solid line: Share of countries imposing thin-capitalization rules in \% measured on the left axis. Dotted line: mean value of the safe haven debt-to-equity ratio among OECD countries with existing thin-capitalization rules measured on the right axis. Source: see the Appendix. 
While country-specific information is provided by Table A.1 in the Appendix, the solid line in Figure 1 indicates the share of OECD countries that have implemented such rules in the time period from 1996 until 2009. The dashed line reports the average safe haven debt-to-equity ratio implemented. ${ }^{6}$ While the average tightness of the rules proves constant, more and more countries have implemented such rules.

For purposes of the empirical analysis below, note that the untransformed safe haven ratio is not a useful measure of thin-capitalization restrictions, as it is infinitely large if no restriction is imposed. Following Buettner et al. (2012), we make use of a simple, non-linear transformation of the safe haven debt-to-equity ratio denoted by $\sigma$ and employ the following indicator of the tightness of the thin-capitalization rule applied to subsidiary $i$ in period $t$

$$
\mathrm{TCR}_{i t} \equiv \frac{1}{1+\sigma_{i t}}
$$

The advantage of this indicator is that it maps the complete possible range of $\sigma$ in the $0-1$ interval. If no restriction is imposed $(\sigma \rightarrow \infty)$, the indicator is zero. In the hypothetically most restrictive case $(\sigma \rightarrow 0)$, the indicator has unit value. ${ }^{7}$ For a numerical example, consider the Canadian case, where the safe haven debt-to-equity ratio was 3:1 during the nineties. In this case, $\sigma$ was 3 , and the indicator was $0.25\left(=\frac{1}{1+3}\right)$. In 2001, when the Canadian safe haven debt-to-equity ratio was

\footnotetext{
${ }^{6}$ Although countries often establish special rules for financial institutions and holdings, we do not report these ratios here as the corresponding subsidiaries are excluded from our empirical analysis. For instance, financial institutions in Australia enjoy a more generous debt-to-equity rule similar to banks and insurance companies in South Korea, or holding companies in Germany up to 2003. Similar exceptions hold in the Czech Republic and in Mexico.

${ }^{7}$ The tightness indicator can be interpreted as the minimum share of capital that needs to be financed with equity capital in order to avoid tax penalties. To see this, note from above that interest deduction is not restricted if debt obeys $D \leq \sigma E$. Denote the share of equity capital with $\varepsilon$. Then $1-\varepsilon \leq \sigma \varepsilon$ and $\varepsilon \geq \frac{1}{1+\sigma}$.
} 
tightened to $2: 1$, the indicator increased to $0.33\left(=\frac{1}{1+2}\right)$.

While we have been focusing here on the safe haven debt-to-equity ratio, further details of thincapitalization rules differ between countries. Not only is the tax-penalty depending on the statutory tax rate, which is taken into account in the empirical analysis below by an interaction term. In some countries, interest payments for which deduction is denied are reclassified as dividend payments, which implies that additional withholding taxes may be due. Moreover, as discussed in Buettner et.al. (2012), in some countries the debt-to-equity ratio refers to total debt; in the others it refers only to loans provided by the shareholder (parent) and to all loans from related parties. As a robustness check, therefore, in the empirical analysis, we also consider a binary variable ThinCapitalization Rule Exists (TCR - Exists) which ignores the information about the safe haven debt-to-equity ratio and just focuses on whether a thin-capitalization rule is imposed or not.

\subsection{Transfer-Pricing Regulations}

The separate accounting principle requires MNCs to assign prices to all intrafirm deliveries of goods and services and to the licences for patents and trademarks that are used by a subsidiary. Tax planning by multinational firms enters since these prices determine the profit allocation among affiliates. Affiliates located in low-tax countries may charge high prices for intrafirm deliveries and affiliates located in high-tax countries may charge low prices. Firms might also increase intrafirm trade or even shift valuable assets into low-tax subsidiaries in order to charge additional royalties.

In principle, shifting profits by means of transfer pricing is restricted by the so-called arm's length

principle. Accordingly, intrafirm transfer prices should be the same as prices used for transactions 
between independent firms. The issue with applying the arm's length principle is, however, the (in-) comparability of intra-group transfer prices with prices of transactions between unrelated parties. Since intra-group transactions tend to be often firm specific, identification of comparable transactions requires information that is hard to collect or unobservable (see, e.g., Durst and Culbertson, 2003). In practice, different methods are applied to assess whether transfer prices comply with the arm's length principle. The 'comparable uncontrolled price method' and the 'resale price method' rely on publicly available price information. Obviously, when market prices are unobserved, these methods are not feasible and pricing behavior needs to be assessed using firm-specific information. ${ }^{8}$ As a consequence, many countries have implemented transfer-pricing regulations which define documentation requirements, mostly following the OECD transfer pricing guidelines (OECD, 2011).

Lohse, Riedel and Spengel (2012) provide a classification of the strictness of transfer-pricing regulations. Following this classification, a strict regulation is characterized by fewer exemptions, the requirement of an extensive documentation and high penalties. The classification by Lohse et al. (2012) particularly emphasizes the documentation requirements. It groups countries into six classes with similar transfer-pricing regulations. While class 0 comprises countries with no documentation requirements, countries assigned to class 5 demand full disclosure. Table A.2 provides the strictness of transfer-pricing regulations for each country. The average value of the indicator as provided by Lohse et al. (2012) is depicted by the solid line in Figure 2. Since the indicator only provides an ordinal scaling of the strictness of transfer-pricing regulations, the empirical analysis basically focuses on a binary variable Strict Transfer-Pricing Regulation (TPR), which is unity if

\footnotetext{
${ }^{8}$ Examples are the 'cost plus method', the 'transactional profit-split method', or the 'transactional net-margin method'.
} 
the transfer-pricing regulations are assigned to one of the two top classes (class 4 or 5). As also shown in Figure 2, almost two thirds of all OECD countries are imposing such restrictions. As a robustness check, the empirical analysis below also uses the Score of Transfer-Pricing Regulation (TPR - Score), which captures the original classification by Lohse et al. (2012).

\subsection{Implications for Foreign Direct Investment}

As is well established in the literature, in a setting with exemption of foreign earnings, or deferral, the host-country tax rate is an important determinant of foreign direct investment (e.g., Janeba, 1995). Since tax planning of multinational firms tends to reduce the effective tax burden, at a given tax rate, restricting tax-planning opportunities will tend to reduce foreign direct investment. Hong and Smart (2010), for instance, discuss the effects of a general restriction of the interest deductibility. ${ }^{9}$ In their model, each firm can deduct a fraction of interest expenses associated with loans from a tax haven subsidiary. The cost of capital is increased if the fraction of deductible interest expenses is reduced. Moreover, a tax-rate change has a stronger effect on the cost of capital if interest deductibility is restricted. These implications carry over to actual thin-capitalization restrictions.

To see this, consider a set of foreign subsidiaries, some of which finance their investments with internal debt from low-tax affiliates and, therefore, enjoy a relatively low effective tax burden. Now suppose a thin-capitalization rule is introduced. The firms that make heavy use of internal debt finance will find themselves in a situation with excess debt, i.e. with debt exceeding the threshold

\footnotetext{
${ }^{9}$ Also Haufler and Runkel (2012) provide a theoretical analysis of tax planning with restrictions of the interest deductibility.
} 
Figure 2: Transfer-Pricing Regulations among OECD countries

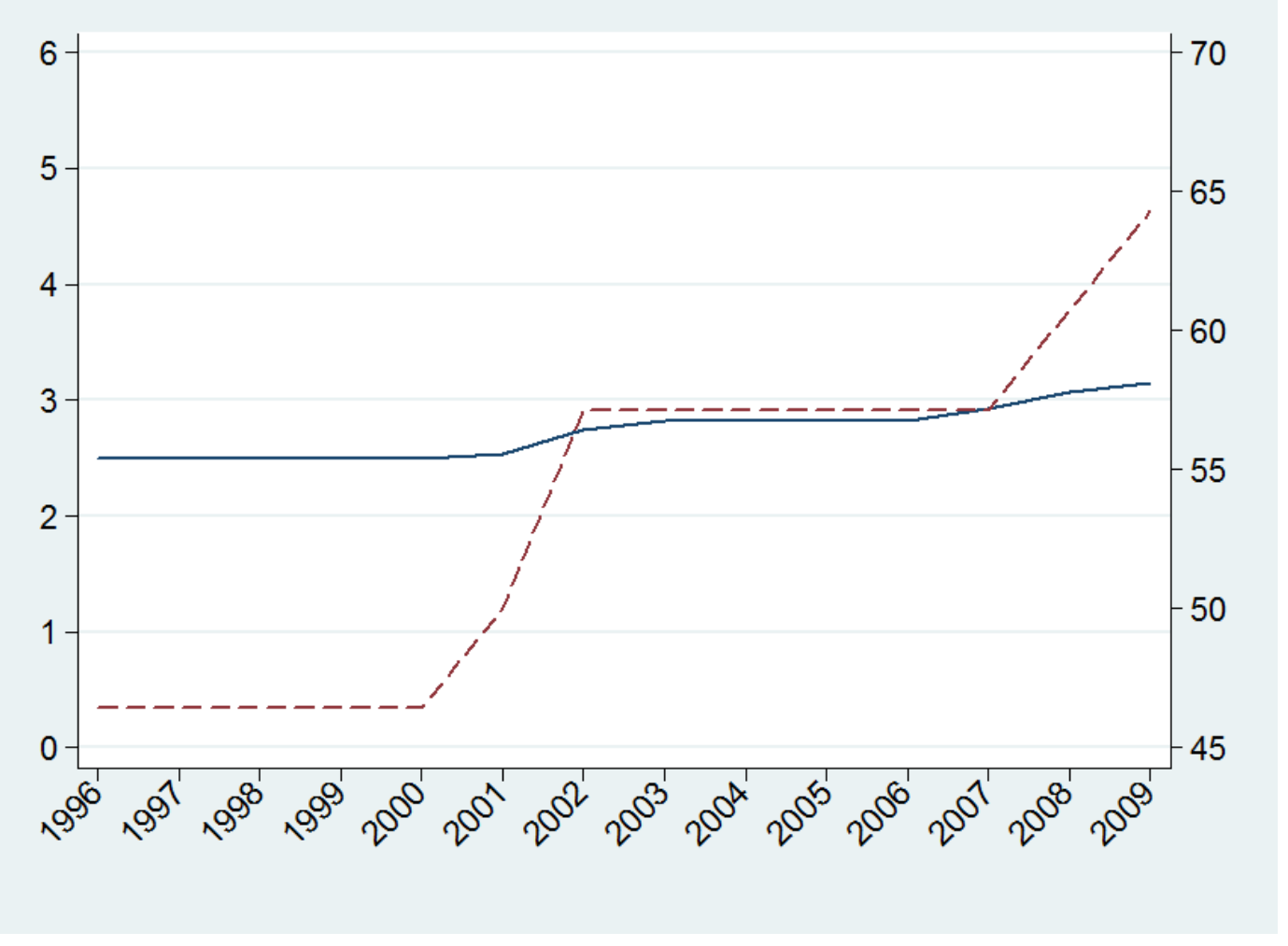

Solid line: Mean level of strictness of transfer-pricing regulations imposed among OECD countries measured on the left axis. Dashed-line: Share of countries with strict regulations in \% measured on the right axis. Source: own computations based on Lohse et al. (2012). 
level defined by the safe haven debt-to-equity ratio. As a consequence, some part of the interest deduction will be denied, and the tax burden is increased at the given tax rate. Ceteris paribus, this will tend to depress foreign direct investment. If firms adjust and reduce internal debt finance, the tax burden would also increase, since the firms would then rely on less tax-efficient financing. A further implication arises with regard to changes in the statutory tax rate. In presence of a thincapitalization rule, if the tax rate is increased, for firms with restricted interest deductibility, the tax shield from internal debt finance is less effective. Hence, the effective tax burden will increase more strongly. Thus, the tax-rate sensitivity of foreign direct investment might increase in the presence of a thin-capitalization restriction.

Of course, firms that make little use of internal debt tend to be below the safe haven debt-to-equity ratio and do not face any denial of interest deductibility. These firms would not be affected by the introduction of thin-capitalization rules. But, the higher the tax rate is, the more likely it is to find firms which are subject to the limitation of interest deduction. Therefore, introducing thincapitalization rules or making them tighter should have adverse effects on foreign direct investment, particularly in countries with high tax rates.

With regard to transfer-pricing regulations, the predictions are similar. If a country imposes strict transfer-pricing regulations, firms might find it more difficult to engage in profit shifting. As a consequence, the tax burden on foreign direct investment would increase. We also expect that an increase in the tax rate has a stronger adverse effect on foreign direct investment since the tax shield from transfer pricing is less effective. Moreover, since the extent to which firms engage in profit-shifting activities will be increasing with the host country's tax rate, the imposition of strict transfer pricing regulations should have stronger adverse effects in countries with high tax rates. 


\section{Data and Investigation Approach}

Our empirical analysis is based on annual subsidiary-level data for German multinational firms in the period from 1996 to 2007 taken from the Microdatabase Direct Investment (MIDI) made available by the German central bank (Deutsche Bundesbank). This data-set includes a number of balance-sheet variables at the subsidiary level and some additional information on location, industry classification, and on the parent firm (see Lipponer, 2006). We focus on wholly-owned foreign subsidiaries and exclude subsidiaries belonging to the financial sector, holding companies, and subsidiaries active in agriculture, forestry, mining, or quarrying, where specific tax conditions apply.

The key indicator of foreign direct investment used in the analysis below is the value of property, plant, and equipment (PPE) reported for subsidiary $i$ at time $t$. Tax effects on PPE will comprise both mobility and substitution effects. Mobility effects arise if multinationals respond to changes in the effective tax burden with a reallocation of production among different locations. Substitution effects occur if individual subsidiaries adjust their production process and substitute capital with other factors such as labor.

As an alternative indicator of production activities by foreign subsidiaries we also consider the level of employment by the foreign subsidiary. As with PPE, tax effects on employment will also reflect mobility and substitution effects. Of course, with taxes imposed on capital income, the substitution effect would be different. If higher taxes induce individual subsidiaries to substitute capital with labor, a positive effect on employment emerges. But the mobility effect of a higher tax burden would result in adverse employment effects. Even without making assumptions about 
the actual magnitude of the substitution elasticity, the comparison between employment and PPE effects enables us to make a qualitative statement regarding the importance of mobility effects.

To test for the effects of taxes, we include the host country's statutory corporation tax rate. To capture the effects of anti-profit-shifting rules, we use indicators for the respective legislation in the host country as discussed in the previous section. Let us denote the indicator applicable to subsidiary $i$ with $I_{i t}$ capturing thin-capitalization rules or transfer pricing regulations $I_{i t} \in$ $\left\{T C R_{i t} ; T P R_{i t}\right\}$. In order to test whether the anti profit-shifting rules affect the tax-sensitivity of investment we include the statutory tax rate applicable to subsidiary $i, S T R_{i t}$, and specify the following equation:

$$
\ln F D I_{i t}=\alpha_{1} \cdot S T R_{i t}+\alpha_{2} \cdot\left(S T R_{i t} \cdot I_{i t}\right)+\alpha_{3} \cdot I_{i t}+\beta \cdot X_{i t}+\phi_{i}+\psi_{t}+\epsilon_{i t},
$$

where $\phi_{i}$ refers to subsidiary-specific fixed effects, $\psi_{t}$ are aggregate time effects, $\epsilon_{i t}$ is an error term, and $X_{i t}$ is a vector of additional controls.

With this specification, we can test for the effects of both the statutory tax rate $S T R_{i t}$ and of anti profit-shifting provisions $I_{i t}$ on the foreign direct investment position. More specifically, the marginal effects are

$$
\frac{\partial \ln F D I_{i t}}{\partial S T R_{i t}}=\alpha_{1}+\alpha_{2} I_{i t}, \quad \frac{\partial \ln F D I_{i t}}{\partial I_{i t}}=\alpha_{3}+\alpha_{2} S T R_{i t} .
$$

With $\alpha_{1}, \alpha_{2}<0$ we would confirm the above hypothesis that the tax-sensitivity increases in the presence of anti profit-shifting rules. Moreover, with $\alpha_{2}<-\frac{\alpha_{3}}{S T R_{i t}}$, imposing a thin-capitalization rule or making it more tight would depress foreign direct investment. Of course, this condition is 
more likely to be met in case of a high-tax country.

$X_{i t}$ includes variables capturing specific characteristics of the subsidiary and the host country. This includes the $(\log )$ sales of the subsidiary and a binary variable which captures the presence of loss carryforwards. We also include host-country variables taken from the World Bank's World Development Indicators to control for market size effects $(\log G D P)$, the dynamics of the host market (GDP growth), and for labor productivity at the location of the subsidiary (log GDP per capita). To capture financial market conditions, we include the inflation rate and Financial Freedom, an indicator of the institutional conditions for financial markets taken from the Heritage indicators database. From the latter source we also include an indicator of corruption, i.e. the Freedom from Corruption.

Equation (2) is estimated using a sample of 21,278 foreign subsidiaries of 5,267 multinationals operations in 39 countries over 12 years. Descriptive statistics for all variables are presented in Table 1.

\section{Basic Results}

Basic regression results are displayed in Table 2. The dependent variable is the foreign subsidiary's stock of property, plant, and equipment (PPE). The empirical analysis follows the approach described in Section 3. All specifications include time - and subsidiary fixed effects. To take account of possible correlation between observations across time, we employ robust standard errors that are

clustered at the level of subsidiaries. Since the tax indicators vary by country-year cells, correlation 
Table 1: Descriptive Statistics

\begin{tabular}{l|cc}
\hline \hline & Mean & Std. Dev. \\
\hline Firm Variables: & & \\
Property, Plant, and Equipment (PPE) & 17,024 & 194,169 \\
Total Assets & 56,999 & $1,260,207$ \\
Number of Employees & 228 & 1,007 \\
Sales & 80,167 & 716,943 \\
Loss Carryforward & .324 & .468 \\
Tax Variables: & & \\
STR & & \\
Thin-Capitalization Rule Tightness (TCR) & .328 & .068 \\
Thin-Capitalization Rule Exists (TCR - Exists) & .229 & .170 \\
Strict Transfer-Pricing Regul. (TPR) & .717 & .451 \\
Score of Transfer-Pricing Regul. (TPR-Score) & .403 & .490 \\
High Tax & 2.92 & 1.07 \\
& .104 & .306 \\
Additional Controls: & & \\
GDP & & \\
GDP Growth & 2,050 & 3,350 \\
GDP per Capita & .032 & .220 \\
Inflation Rate & 26,095 & 13,877 \\
Financial Freedom & .029 & .091 \\
Freedom from Corruption & 70.0 & 17.6 \\
& 68.2 & 19.7 \\
\hline
\end{tabular}

Statistics refer to 94,187 observations of foreign subsidiaries of German MNCs. Firm-level variables are taken from the MiDi database made available by Deutsche Bundesbank. Fixes Assets, Total Assets and Sales are in $€ 1,000$. Loss Carryforward is a binary variable which is one if subsidiary has a loss carryforward. STR is the statutory corporate income tax rate. Information on thin-capitalization rules is taken from Buettner et al. (2012), see appendix, while data on transfer-pricing regulations are taken from Lohse et al. (2012). TCR is the minimum share of equity stipulated by the thin-capitalization rule of the borrowing entity's host country. TCR Exists is a dummy variable which is one if a host country applies a thin-capitalization rule. TPR Score is the classification of transfer-pricing regulation by Lohse et al. (2012). The scores range from 0 (no transfer-regulations) to 5 (very strict transfer-pricing regulation). $T P R$ is a dummy variable which is one if transfer-pricing regulation have been classified as very strict (score values 4 or 5). GDP (billion US dollars, current prices), GDP per Capita (US dollars, current prices), GDP Growth, and Inflation Rate (consumer prices) are taken from the IMF World Development Indicators. Financial Freedom and Freedom from Corruption are taken from the Heritage Database. Scores range from 0 to 100. 
within country-year cells may also constitute a problem. We, therefore, employ a two-dimensional cluster which also takes account of country-year cells.

Specification (1) in Table 2 only considers the statutory tax rate and a basic set of control variables. In accordance with theoretical predictions, a higher statutory tax rate is associated with a lower level of FDI. The point estimate suggests that a one percentage point higher tax rate is associated with 0.83 percent less investment in fixed assets. This basic estimate is broadly in line with the existing literature on how FDI responds to higher host-country corporation tax rates. ${ }^{10}$

With regard to other firm-level variables, we find significant effects for both sales and the existence of a loss carry-forward. Sales show a positive coefficient possibly pointing at firm-size effects. The negative effect of a loss carry-forward might point at significant investment in the past, but could also reflect unfavorable profit prospects. We do not find significant effects of the size of the host country's local market as indicated by the GDP. At first sight, this may seem surprising, but it should be taken into account that estimations include subsidiary-specific fixed effects which nest country-level fixed effects. Therefore, all cross-sectional differences between host countries are removed entirely. The lack of variation might also explain why the inflation rate, financial freedom and freedom from corruption prove insignificant. GDP per capita, which is included as a proxy for labor productivity, shows a positive and statistically significant effect.

In Columns (2) - (4) of Table 2 we take into account indicators of anti profit-shifting legislation.

\footnotetext{
${ }^{10}$ For surveys, see DeMooij and Ederveen (2003) or Feld and Heckemeyer (2011). In a meta-analysis, Feld and Heckemeyer (2011) find a higher tax effect but also note that studies using micro-level data (like our study) typically find significantly smaller tax effects in absolute values. For example, Wamser (2011) uses the same firm-level data and finds a tax semi-elasticity of about -0.5 . Thus, the tax effect of about -0.83 found in column (1) of Table 2 is in accordance with previous findings.
} 
Table 2: Anti Profit-Shifting Rules and Foreign Direct Investment

\begin{tabular}{|c|c|c|c|c|}
\hline & $(1)$ & $(2)$ & $(3)$ & $(4)$ \\
\hline Tax rate (STR) & $\begin{array}{c}-.829^{* * *} \\
(.264)\end{array}$ & $\begin{array}{c}-.586^{* *} \\
(.287)\end{array}$ & $\begin{array}{c}-.930^{* * *} \\
(.310)\end{array}$ & $\begin{array}{c}-.712^{* *} \\
(.322)\end{array}$ \\
\hline Thin-cap.rule (TCR) & & $\begin{array}{l}.765^{*} \\
(.398)\end{array}$ & & $\begin{array}{l}.885^{* *} \\
(.410)\end{array}$ \\
\hline Tax rate $\times$ Thin-cap.rule $(\mathrm{STR} \times \mathrm{TCR})$ & & $\begin{array}{l}-2.17^{*} \\
(1.14)\end{array}$ & & $\begin{array}{c}-2.42^{* *} \\
(1.17)\end{array}$ \\
\hline Transf.-pr.regul. (TPR) & & & $\begin{array}{l}-.101 \\
(.123)\end{array}$ & $\begin{array}{l}-.142 \\
(.120)\end{array}$ \\
\hline Tax rate $\times$ Transf.pr.regul. $(\mathrm{STR} \times \mathrm{TPR})$ & & & $\begin{array}{c}.161 \\
(.369)\end{array}$ & $\begin{array}{c}.261 \\
(.355)\end{array}$ \\
\hline $\ln$ (Sales) & $\begin{array}{l}.400^{* * *} \\
(.013)\end{array}$ & $\begin{array}{c}.400^{* * *} \\
(.013)\end{array}$ & $\begin{array}{c}.400^{* * *} \\
(.013)\end{array}$ & $\begin{array}{c}.400^{* * *} \\
(.013)\end{array}$ \\
\hline Loss Carryforward & $\begin{array}{c}-.040^{* * *} \\
(.012)\end{array}$ & $\begin{array}{c}-.040^{* * *} \\
(.012)\end{array}$ & $\begin{array}{c}-.040^{* * *} \\
(.012)\end{array}$ & $\begin{array}{c}-.039^{* * *} \\
(.012)\end{array}$ \\
\hline $\ln (\mathrm{GDP})$ & $\begin{array}{l}-.150 \\
(.461)\end{array}$ & $\begin{array}{l}-.058 \\
(.477)\end{array}$ & $\begin{array}{l}-.125 \\
(.460)\end{array}$ & $\begin{array}{l}.011 \\
(.477)\end{array}$ \\
\hline GDP Growth & $\begin{array}{l}-.052 \\
(.348)\end{array}$ & $\begin{array}{l}-.005 \\
(.347)\end{array}$ & $\begin{array}{l}-.153 \\
(.348)\end{array}$ & $\begin{array}{l}-.116 \\
(.348)\end{array}$ \\
\hline $\ln ($ GDP per Capita) & $\begin{array}{l}.845^{*} \\
(.454)\end{array}$ & $\begin{array}{l}.745 \\
(.459)\end{array}$ & $\begin{array}{l}.823^{*} \\
(.454)\end{array}$ & $\begin{array}{l}.680 \\
(.470)\end{array}$ \\
\hline Inflation Rate & $\begin{array}{c}.036 \\
(.028)\end{array}$ & $\begin{array}{c}.041 \\
(.026)\end{array}$ & $\begin{array}{c}.034 \\
(.028)\end{array}$ & $\begin{array}{c}.042 \\
(.027)\end{array}$ \\
\hline Financial Freedom & $\begin{array}{l}.000 \\
(.001)\end{array}$ & $\begin{array}{c}.000 \\
(.001)\end{array}$ & $\begin{array}{l}.000 \\
(.001)\end{array}$ & $\begin{array}{c}.001 \\
(.001)\end{array}$ \\
\hline Freedom from Corruption & $\begin{array}{l}-.001 \\
(.001)\end{array}$ & $\begin{array}{l}-.001 \\
(.001)\end{array}$ & $\begin{array}{l}-.001 \\
(.001)\end{array}$ & $\begin{array}{l}.000 \\
(.001)\end{array}$ \\
\hline Observations & 94,187 & 94,187 & 94,187 & 94,187 \\
\hline Adj. $R^{2}$ & .1069 & .1071 & .1070 & .1072 \\
\hline
\end{tabular}

Dependent variable is property, plant, and equipment (PPE) in logs. TCR is measured by the transformation of the safe haven debt-to-equity ratio, see above. $T P R$ is a dummy variable indicating if transfer-pricing regulations have been classified by Lohse et al. (2012) as strict. Estimations include time-specific and subsidiary-specific fixed effects. Robust standard errors, clustered at subsidiary and country-year cells, are in parentheses. ${ }^{* * *},{ }^{* * *}$ denote significance at the $10 \%, 5 \%$, and $1 \%$ level. 
As explained above, since the incentive to engage in profit shifting increases with the tax rate, it is important to include interaction terms between the tax rate and the respective indicators for anti profit-shifting legislation. The interaction term between the tax rate and the tightness of the thincapitalization rule shows a significant negative effect on investment. This supports the view that a tax increase is associated with a stronger response of foreign direct investment under restrictions of interest deduction. The interaction with the transfer-pricing regulation indicator is not significant, however.

Due to the significant interaction term, the marginal effects of statutory tax rate and thin-capitalization restriction cannot be directly inferred from the slope parameters. Consider the results of specification (2). Evaluating the point estimates at mean tightness of the thin-capitalization rule (with $\overline{T C R}=0.25$ or a safe haven debt-to-equity ratio of $3: 1$ ), the marginal effect of the statutory tax rate is

$$
\frac{\partial \ln \widehat{F D} I_{i t}}{\partial S T R_{i t}}=-0.586-2.17 \cdot \overline{T C R}=-0.586-2.17 \cdot 0.25=-1.13
$$

Accordingly, the tax-rate sensitivity of foreign direct investment is about twice as large (-1.13) as in the unrestricted case $(-0.586)$.

Using a mean value for the statutory tax rate $(\overline{S T R}=0.33)$, the marginal effect of the tightness of the thin-capitalization rule is

$$
\frac{\partial \ln \widehat{F D} I_{i t}}{\partial I_{i t}}=0.765-2.17 \cdot \overline{S T R}=0.765-2.17 \cdot 0.33=0.049
$$

The small effect indicates that, evaluated at the average tax rate, introducing a thin-capitalization rule or making it more tight does not exert foreign direct investment effects. However, in countries 
where the tax rate is above the average, imposing a thin-capitalization rule or making it more tight will tend to have adverse effects. Consider a host country where the tax rate exceeds the mean tax rate by one standard deviation and, thus, has a value of $40 \%$. Evaluating the marginal effect at this tax rate yields

$$
\frac{\partial \ln \widehat{F D} I_{i t}}{\partial I_{i t}}=0.765-2.17 \cdot 0.40=-0.103
$$

This point estimate suggests that, if the high-tax country implements a thin-capitalization rule with mean level of tightness (0.25), foreign direct investment declines by about 2.5 percent.

\section{$5 \quad$ Robustness and Employment Effects}

To check for robustness, we carry out several additional regressions. A first set of results is shown in Table 3. Specifications (1) and (2) deal with potential spurious correlation associated with the interaction term between the tax rate and anti profit-shifting rules, that might arise if high-tax countries have a higher propensity to implement such measures.

In column (1) we test whether the results are robust against inclusion of a non-linear tax effect by adding the tax rate squared. In specification (2) we include a dummy identifying tax countries with above average tax rates - also as an interaction effect - to test whether interaction effects between the tax rate and anti profit-shifting measures are driven specifically by high-tax countries in the sample. Yet the results in columns (1) and (2) show that the interaction with anti-profit shifting rules does not pick up non-linear tax effects.

In columns (3) and (4) we consider alternative proxies for the anti profit-shifting rules. In column 
Table 3: Robustness Analysis

\begin{tabular}{|c|c|c|c|c|}
\hline & $(1)$ & $(2)$ & $(3)$ & $(4)$ \\
\hline Tax rate $(\mathrm{STR})$ & $\begin{array}{c}-1.88^{* *} \\
(.962)\end{array}$ & $\begin{array}{c}-.736^{* *} \\
(.329)\end{array}$ & $\begin{array}{c}-.682^{* *} \\
(.312)\end{array}$ & $\begin{array}{l}-.703^{*} \\
(.421)\end{array}$ \\
\hline Thin-cap.rule (TCR) & $\begin{array}{l}.765^{*} \\
(.412)\end{array}$ & $\begin{array}{l}.893^{* *} \\
(.411)\end{array}$ & $\begin{array}{l}.263^{* *} \\
(.105)\end{array}$ & $\begin{array}{l}.889^{* *} \\
(.413)\end{array}$ \\
\hline Tax rate $\times$ Thin-cap.rule $(\mathrm{STR} \times \mathrm{TCR})$ & $\begin{array}{l}-2.06^{*} \\
(1.19)\end{array}$ & $\begin{array}{c}-2.49^{* *} \\
(1.17)\end{array}$ & $\begin{array}{c}-.763^{* *} \\
(.304)\end{array}$ & $\begin{array}{c}-2.48^{* *} \\
(1.18)\end{array}$ \\
\hline Transf.-pr.regul. (TPR) & $\begin{array}{l}-.100 \\
(.120)\end{array}$ & $\begin{array}{l}-.135 \\
(.120)\end{array}$ & $\begin{array}{l}-.154 \\
(.119)\end{array}$ & $\begin{array}{l}-.036 \\
(.042)\end{array}$ \\
\hline Tax rate $\times$ Transf.pr.regul. $(\mathrm{STR} \times \mathrm{TPR})$ & $\begin{array}{l}.126 \\
(.354)\end{array}$ & $\begin{array}{l}.261 \\
(.354)\end{array}$ & $\begin{array}{l}.285 \\
(.350)\end{array}$ & $\begin{array}{l}.051 \\
(.127)\end{array}$ \\
\hline Tax rate, squared $\left(\mathrm{STR}^{2}\right)$ & $\begin{array}{l}1.75 \\
(1.28)\end{array}$ & & & \\
\hline High tax & & $\begin{array}{l}-.011 \\
(.032)\end{array}$ & & \\
\hline High tax $\times$ Thin-cap.rule $(\mathrm{TCR})$ & & $\begin{array}{l}.153 \\
(.122)\end{array}$ & & \\
\hline High tax $\times$ Transf.pr.regul. (TPR) & & $\begin{array}{c}.001 \\
(.040)\end{array}$ & & \\
\hline $\ln$ (Sales) & $\begin{array}{c}.400^{* * *} \\
(.013)\end{array}$ & $\begin{array}{c}.400^{* * *} \\
(.013)\end{array}$ & $\begin{array}{c}.400^{* * *} \\
(.013)\end{array}$ & $\begin{array}{c}.400^{* * *} \\
(.013)\end{array}$ \\
\hline Loss Carryforward & $\begin{array}{c}-.039^{* * *} \\
(.012)\end{array}$ & $\begin{array}{c}-.039^{* * *} \\
(.012)\end{array}$ & $\begin{array}{c}-.039^{* * *} \\
(.012)\end{array}$ & $\begin{array}{c}-.039^{* * *} \\
(.012)\end{array}$ \\
\hline $\ln (\mathrm{GDP})$ & $\begin{array}{l}.119 \\
(.492)\end{array}$ & $\begin{array}{l}-.073 \\
(.476)\end{array}$ & $\begin{array}{l}-.007 \\
(.475)\end{array}$ & $\begin{array}{l}-.040 \\
(.477)\end{array}$ \\
\hline GDP Growth & $\begin{array}{l}-.172 \\
(.345)\end{array}$ & $\begin{array}{l}-.072 \\
(.350)\end{array}$ & $\begin{array}{l}-.218 \\
(.344)\end{array}$ & $\begin{array}{l}-.134 \\
(.349)\end{array}$ \\
\hline $\ln ($ GDP per Capita) & $\begin{array}{l}.598 \\
(.486)\end{array}$ & $\begin{array}{l}.770 \\
(.469)\end{array}$ & $\begin{array}{l}.692 \\
(.469)\end{array}$ & $\begin{array}{l}.740 \\
(.471)\end{array}$ \\
\hline Inflation Rate & $\begin{array}{c}.042 \\
(.027)\end{array}$ & $\begin{array}{l}.043 \\
(.027)\end{array}$ & $\begin{array}{l}.040 \\
(.027)\end{array}$ & $\begin{array}{l}.042 \\
(.025)\end{array}$ \\
\hline Financial Freedom & $\begin{array}{l}.001 \\
(.001)\end{array}$ & $\begin{array}{l}.001 \\
(.001)\end{array}$ & $\begin{array}{l}.001 \\
(.001)\end{array}$ & $\begin{array}{l}.001 \\
(.001)\end{array}$ \\
\hline Freedom from Corruption & $\begin{array}{l}.000 \\
(.001)\end{array}$ & $\begin{array}{l}.000 \\
(.001)\end{array}$ & $\begin{array}{l}.000 \\
(.001)\end{array}$ & $\begin{array}{l}.000 \\
(.001)\end{array}$ \\
\hline $\begin{array}{l}\text { Observations } \\
\text { Adj. } R^{2}\end{array}$ & $\begin{array}{c}94,187 \\
.1073\end{array}$ & $\begin{array}{l}94,187 \\
.1073\end{array}$ & $\begin{array}{c}94,187 \\
.1073\end{array}$ & $\begin{array}{c}94,187 \\
.1072\end{array}$ \\
\hline
\end{tabular}

Dependent variable is property, plant, and equipment (PPE) in logs. In columns (1), (2) and (4), TCR is measured by the transformation of the safe haven debt-to-equity ratio, see above. In column (3) the $T C R$ is a dummy variable indicating if a thin-capitalization rule exists. In columns (1) - (3), the TPR is a dummy variable indicating if transfer-pricing regulations have been classified by Lohse et al. (2012) as strict, while column (4) considers the complete transfer-pricing score as proposed by Lohse et al. (2012). Estimations include time-specific and subsidiaryspecific fixed effects. Robust standard errors, clustered at subsidiary and country-year cells, are in parentheses. ${ }^{*},{ }^{* *},{ }^{* * *}$ denote significance at the $10 \%, 5 \%$, and $1 \%$ level. 
(3), we employ a simple binary variable for the existence of a thin-capitalization rule. Estimation results confirm our findings from the basic specifications in Table 2. More specifically, regardless of the level of the safe have debt-to-equity ratio, the existence of a thin-capitalization rule is associated with a higher tax-rate effect on foreign direct investment. In column (4) we substitute the binary indicator for transfer-pricing regulations with the original indicator by Lohse et al. (2012). Nevertheless, we are still unable to detect any statistically significant foreign direct investment effect of host country transfer-pricing regulations.

A second set of additional regressions is presented in Table 4. While the specifications are similar to Table 2, Table 4 considers the effects obtained with the log number of employees as dependent variable. Again, we do not find effects of transfer-pricing regulations. However, as above, the tightness of the thin-capitalization rule exerts adverse effects. Following the above procedure, we can compute the marginal effect of the statutory corporation tax rate at the mean level of tightness (0.25) and obtain

$$
\frac{\partial \ln \widehat{F D} I_{i t}^{e m p}}{\partial S T R_{i t}}=-0.085-1.31 \cdot \overline{T C R},=-0.085-1.31 \cdot 0.25=-0.41
$$

Accordingly, in presence of a typical thin-capitalization rule, raising the statutory corporation tax rate by a percentage point is associated with a decline of employment of foreign subsidiaries by -0.4 percent. However, if there are no thin-capitalization restrictions, the tax rate has only insignificant effects on employment. While the result is qualitatively similar to the effect on PPE, the lower tax-sensitivity points at some capital-labor substitution effects in the sense that subsidiaries in hightax countries tend to substitute capital with labor. However, in the presence of thin-capitalization restrictions, the adverse mobility effect dominates. 
Table 4: Employment Effects

\begin{tabular}{l|cccc}
\hline \hline & & & & \\
& & & & \\
& & & & \\
& -.067 & -.085 & -.093 & .216 \\
Tax rate (STR) & $(.144)$ & $(.157)$ & $(.174)$ & $(.179)$ \\
& & $.494^{* *}$ & & $.499^{* *}$ \\
Thin-cap.rule (TCR) & & $(.239)$ & & $(.239)$ \\
& & $-1.31^{* *}$ & & $-1.36^{* *}$ \\
Tax rate $\times$ Thin-cap.rule (STR $\times$ TCR) & & $(.664)$ & & $(.657)$ \\
Transf.-pr.regul. (TPR) & & & .066 & .043 \\
& & & $(.072)$ & $(.074)$ \\
Tax rate $\times$ Transf.pr.regul. (STR $\times$ TPR) & & & -.291 & -.236 \\
& & & $(.212)$ & $(.215)$ \\
$\ln$ (Sales) & & & & \\
& $.447^{* * *}$ & $.447^{* * *}$ & $.447^{* * *}$ & $.447^{* * *}$ \\
Loss Carryforward & $(.009)$ & $(.009)$ & $(.009)$ & $(.009)$ \\
$\ln ($ GDP) & $-.036^{* * *}$ & $-.036^{* * *}$ & $-.036^{* * *}$ & $-.036^{* * *}$ \\
& $(.006)$ & $(.006)$ & $(.006)$ & $(.006)$ \\
GDP Growth & -.279 & -.195 & -.279 & -.201 \\
& $(.249)$ & $(.253)$ & $(.248)$ & $(.250)$ \\
$\ln$ (GDP per Capita) & $.786^{* * *}$ & $.824^{* * *}$ & $.756^{* * *}$ & $.778^{* * *}$ \\
Inflation Rate & $(.240)$ & $(.240)$ & $(.243)$ & $(.242)$ \\
& .338 & .252 & .345 & .264 \\
Financial Freedom & $(.250)$ & $(.253)$ & $(.248)$ & $(.250)$ \\
Freedom from Corruption & -.014 & -.009 & -.017 & -.012 \\
& $(.015)$ & $(.013)$ & $(.015)$ & $(.014)$ \\
Observations & .000 & .000 & .000 & .000 \\
$\mathrm{R}^{2}$ & $(.000)$ & $(.000)$ & $(.000)$ & $(.000)$ \\
\hline & -.000 & -.000 & -.000 & -.000 \\
& $(.000)$ & $(.000)$ & $(.000)$ & $(.000)$ \\
\hline & 92,582 & 92,582 & 92,582 & 92,582 \\
& .2799 & .2799 & .2800 & .2802 \\
\hline
\end{tabular}

Dependent variable is $\ln$ (Number of Employees) in columns (1) - (4). TCR is measured by the transformation of the safe haven debt-to-equity ratio, see above. TPR is a dummy variable indicating if transfer-pricing regulations have been classified by Lohse et al. (2012) as strict. Estimations include time-specific and subsidiary-specific fixed effects. Robust standard errors, clustered at subsidiary and country-year cells, are in parentheses. ${ }^{*},{ }^{* *},{ }^{* * *}$ denote significance at the $10 \%, 5 \%$, and $1 \%$ level. 
Evaluated at the mean tax rate, we can also explore the marginal effect of the tightness of the thin-capitalization rule on employment as

$$
\frac{\partial \ln \widehat{F D} I_{i t}^{e m p}}{\partial I_{i t}}=0.494-1.31 \cdot \overline{S T R}=0.494-1.31 \cdot 0.33=0.062
$$

The small effect confirms the above finding that imposing thin-capitalization restrictions has no effect on MNCs' FDI in countries with an average tax rate. Only for countries with high tax rates, the results point at some adverse employment effect of introducing a thin-capitalization rule or making it more tight.

\section{Conclusion}

This paper has studied the effects of host countries' anti profit-shifting measures on foreign direct investment. More specifically, the empirical analysis has considered whether limitations on the two main profit-shifting channels - debt financing and transfer pricing - exert adverse effects on foreign direct investment. The empirical results show that restrictions of the interest deductibility, so-called thin-capitalization rules, are associated with a decline of foreign direct investment - if imposed by host countries with relatively high tax rates. More specifically, we find that if a country with a corporation tax rate exceeding the average tax-rate by one standard deviation implements a typical thin-capitalization rule, foreign direct investment declines by about 2.5 percent. Moreover, we find that the sensitivity of foreign direct investment with regard to the host-country tax rate increases if such restrictions are imposed or tightened. On average, we find that the tax-rate elasticity of foreign direct investment almost doubles if, for example, a typical thin-capitalization rule with a debt-to-equity ratio of $3: 1$ is implemented compared with a case where no such restriction is 
present. We have shown that this finding does not simply reflect the larger propensity of hightax countries to implement such measures. Moreover, a consideration of employment by foreign subsidiaries suggests that the empirical effects of thin-capitalization rules on capital do not only reflect capital-labor substitution but also adverse mobility effects. We have also explored whether regulations on transfer pricing have similar adverse effects on foreign direct investment, but our results do not point at any significant effects. A possible explanation could be that those restrictions might be ineffective or substituted with other forms of tax planning more easily. But, whereas the restrictions imposed by thin-capitalization rules involve the definition of a safe-haven debt-to-equity ratio, which can be operationalized for empirical purposes rather easily, comparing transfer-pricing regulations across countries is perhaps more difficult. Therefore, the lack of significance of the latter regulations should not be overemphasized.

While the adverse effect on foreign direct investment contributes to lower employment and to a tax revenue loss, a host country government might still prefer to impose anti profit-shifting rules in order to limit tax discrimination against domestic firms. Because the alternative measure to eliminate taxdiscrimination, which is to lower the corporate tax rate also for domestic firms, might involve much larger revenue losses. However, we also find that the tax-rate effect on foreign direct investment increases in the presence of restrictions of the interest deductibility for related party debt. This finding supports the theoretical literature, which suggests that anti profit-shifting measures might lead to more intense tax-competition for foreign direct investment. In the general equilibrium, therefore, attempts to shield corporation tax revenues by combatting MNEs tax planning might be futile.

From this perspective, our results raise concerns about recent initiatives to limit profit shifting by 
multinational firms such as the action plan by the OECD against 'profit shifting and base erosion' (BEPS). Action 4 of the OECD proposal explicitly includes the development of measures to limit base erosion via interest deductions. Our findings suggest that policymakers considering those restrictions should not only take account of adverse effects on foreign direct investment but should also be aware of a higher tax-rate sensitivity of foreign direct investment under such provisions. Intensified tax competition is the likely consequence. In other words, tax policy is facing a trade-off between limiting base erosion and increasing adverse tax effects on foreign direct investment. 


\section{A.1 Datasources}

Micro-Level Data are taken from the micro-level dataset (MiDi) of the Deutsche Bundesbank (see Lipponer, 2006, for an overview) using a version that covers the period from 1996 to 2007.

Corporate Taxation Data are taken from the International Bureau of Fiscal Documentation (IBFD) and from tax surveys provided by Ernst\&Young, PricewaterhouseCoopers (PwC), and KPMG. The statutory tax rate variable contains statutory profit tax rates modified by restrictions on interest deduction - as in the case of the Italian IRAP.

Thin-Capitalization Rules: Basic information about thin-capitalization rules has been obtained from the same sources as the tax data. As in Buettner et al. (2012) this information was augmented and cross-checked with questionnaires sent out to country experts of PricewaterhouseCoopers. Table A.1 provides the safe haven debt-to-equity ratios.

Transfer-Pricing Regulations are taken from the study by Lohse, Riedel and Spengel (2012) who provide a classification of the strictness of national transfer-pricing regulations, see Table A.2 for details. The empirical analysis basically focuses on a binary variable, which is unity if the transfer-pricing regulations are categorized in the two top classes (class 4 or 5).

Macroeconomic Indicators such as GDP and GDP per Capita in US dollars, current prices, as well as GDP Growth and Inflation are taken from the IMF World Development Indicators.

Heritage Indicators: 'Financial Freedom' and 'Freedom from Corruption' are taken from the Heritage Database. Scores range from 0 to 100. 
Table A.1: Thin-Capitalization Debt-to-Equity Ratios

\begin{tabular}{|c|c|c|c|c|c|c|c|c|c|c|c|c|}
\hline Country & 1996 & 1997 & 19998 & 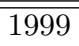 & 2000 & 2001 & 2002 & 2003 & 2004 & 2005 & 2006 & 2007 \\
\hline Australia & 3 & 3 & 2 & 2 & 2 & 2 & 3 & 3 & 3 & 3 & 3 & 3 \\
\hline Belgium & 7 & 7 & 7 & 7 & 7 & 7 & 7 & 7 & 7 & 7 & 7 & 7 \\
\hline Bulgaria & - & - & 2 & 2 & 2 & 2 & 2 & 2 & 2 & 2 & 2 & 3 \\
\hline Canada & 3 & 3 & 3 & 3 & 3 & 2 & 2 & 2 & 2 & 2 & 2 & 2 \\
\hline Croatia & - & - & - & - & - & - & - & - & - & 4 & 4 & 4 \\
\hline Czech Republic & 4 & 4 & 4 & 4 & 4 & 4 & 4 & 4 & 4 & 4 & 4 & 4 \\
\hline Denmark & - & - & - & 4 & 4 & 4 & 4 & 4 & 4 & 4 & 4 & 4 \\
\hline France & 1.5 & 1.5 & 1.5 & 1.5 & 1.5 & 1.5 & 1.5 & 1.5 & 1.5 & 1.5 & 1.5 & 1.5 \\
\hline Germany & 3 & 3 & 3 & 3 & 3 & 1.5 & 1.5 & 1.5 & 1.5 & 1.5 & 1.5 & 1.5 \\
\hline Hungary & - & 4 & 4 & 4 & 4 & 3 & 3 & 3 & 3 & 3 & 3 & 3 \\
\hline Italy & - & - & - & - & - & - & - & - & 5 & 4 & 4 & 4 \\
\hline Japan & 3 & 3 & 3 & 3 & 3 & 3 & 3 & 3 & 3 & 3 & 3 & 3 \\
\hline Lithuania & - & - & - & - & - & - & - & - & 4 & 4 & 4 & 4 \\
\hline Luxembourg & - & - & - & - & - & - & 5.7 & 5.7 & 5.7 & 5.7 & 5.7 & 5.7 \\
\hline Korea & - & 3 & 3 & 3 & 3 & 3 & 3 & 3 & 3 & 3 & 3 & 3 \\
\hline Mexico & - & - & - & - & - & - & - & - & - & 3 & 3 & 3 \\
\hline Netherlands & 3 & 3 & 3 & 3 & 3 & 3 & 3 & 3 & 3 & 3 & 3 & 3 \\
\hline New Zealand & - & 3 & 3 & 3 & 3 & 3 & 3 & 3 & 3 & 3 & 3 & 3 \\
\hline Poland & - & - & - & 3 & 3 & 3 & 3 & 3 & 3 & 3 & 3 & 3 \\
\hline Portugal & 2 & 2 & 2 & 2 & 2 & 2 & 2 & 2 & 2 & 2 & $2^{a}$ & $2^{a}$ \\
\hline Romania & - & - & - & - & - & - & 3 & 3 & 3 & 3 & 3 & 3 \\
\hline Slovakia & 4 & 4 & 4 & 4 & 4 & 4 & 4 & 4 & - & - & - & - \\
\hline Slovenia & - & - & - & - & - & - & - & - & - & 8 & 8 & 8 \\
\hline Spain & 3 & 3 & 3 & 3 & 3 & 3 & 3 & 3 & $3^{a}$ & $3^{a}$ & $3^{a}$ & $3^{a}$ \\
\hline Switzerland & 6 & 6 & 6 & 6 & 6 & 6 & 6 & 6 & 6 & 6 & 6 & 6 \\
\hline Turkey & 2 & 2 & 2 & 2 & 2 & 2 & 2 & 2 & 2 & 2 & 2 & 3 \\
\hline $\mathrm{UK}^{b}$ & 1 & 1 & 1 & 1 & 1 & 1 & 1 & 1 & 1 & 1 & 1 & 1 \\
\hline USA & 1.5 & 1.5 & 1.5 & 1.5 & 1.5 & 1.5 & 1.5 & 1.5 & 1.5 & 1.5 & 1.5 & 1.5 \\
\hline
\end{tabular}

Number of debt units in relation to equity capital which are accepted by the thin-capitalization rules for unrestricted interest deduction from taxable profits. Special rules for financial institutions and holdings are not reported.

${ }^{a}$ Rule does not apply to related party debt provided by a company located in a member state of the European Union. ${ }^{b}$ Since 2004 the UK applies anti-abuse rules employing an arm's length principle, but the safe haven debt-to-equity ratio is still used as a guideline. 
Table A.2: Strictness of Transfer-Pricing Regulation

\begin{tabular}{|c|c|c|c|c|c|c|c|c|c|c|c|c|}
\hline Country & 1996 & 1997 & 1998 & 1999 & 2000 & 2001 & 2002 & 2003 & 2004 & 2005 & 2006 & 2007 \\
\hline Australia & 4 & 4 & 4 & 4 & 4 & 4 & 4 & 4 & 4 & 4 & 4 & 4 \\
\hline Austria & 2 & 2 & 2 & 2 & 2 & 2 & 2 & 2 & 2 & 2 & 2 & 2 \\
\hline Belgium & 3 & 3 & 3 & 3 & 3 & 2 & 2 & 2 & 2 & 2 & 2 & 2 \\
\hline Brasil & 5 & 5 & 5 & 5 & 5 & 5 & 5 & 5 & 5 & 5 & 5 & 5 \\
\hline Bulgaria & 0 & 0 & 0 & 0 & 0 & 0 & 0 & 0 & 0 & 0 & 0 & 2 \\
\hline Canada & 4 & 4 & 4 & 4 & 4 & 4 & 4 & 4 & 4 & 4 & 4 & 4 \\
\hline China & 4 & 4 & 4 & 4 & 4 & 4 & 4 & 4 & 4 & 4 & 4 & 4 \\
\hline Columbia & 2 & 2 & 2 & 2 & 2 & 2 & 2 & 2 & 4 & 4 & 4 & 4 \\
\hline Croatia & 0 & 0 & 0 & 0 & 0 & 0 & 0 & 0 & 0 & 4 & 4 & 4 \\
\hline Czech Republic & 2 & 2 & 2 & 2 & 2 & 2 & 2 & 2 & 2 & 2 & 2 & 2 \\
\hline Denmark & 4 & 4 & 4 & 4 & 4 & 4 & 4 & 4 & 4 & 4 & 4 & 4 \\
\hline Finland & 2 & 2 & 2 & 2 & 2 & 2 & 2 & 2 & 2 & 2 & 2 & 3 \\
\hline France & 2 & 2 & 2 & 2 & 2 & 2 & 2 & 2 & 2 & 2 & 2 & 2 \\
\hline Germany & 2 & 2 & 2 & 2 & 2 & 2 & 2 & 3 & 3 & 3 & 3 & 3 \\
\hline Greece & 1 & 1 & 1 & 1 & 1 & 1 & 1 & 1 & 1 & 1 & 1 & 1 \\
\hline Hungary & 2 & 2 & 2 & 2 & 2 & 2 & 2 & 3 & 3 & 3 & 3 & 3 \\
\hline India & 5 & 5 & 5 & 5 & 5 & 5 & 5 & 5 & 5 & 5 & 5 & 5 \\
\hline Ireland & 1 & 1 & 1 & 1 & 1 & 1 & 1 & 1 & 1 & 1 & 1 & 1 \\
\hline Italy & 4 & 4 & 4 & 4 & 4 & 4 & 4 & 4 & 4 & 4 & 4 & 4 \\
\hline Japan & 4 & 4 & 4 & 4 & 4 & 4 & 4 & 4 & 4 & 4 & 4 & 4 \\
\hline Lithuania & 0 & 0 & 0 & 0 & 0 & 0 & 0 & 0 & 5 & 5 & 5 & 5 \\
\hline Luxembourg & 2 & 2 & 2 & 2 & 2 & 2 & 2 & 2 & 2 & 2 & 2 & 2 \\
\hline Malaysia & 4 & 4 & 4 & 4 & 4 & 4 & 4 & 4 & 4 & 4 & 4 & 4 \\
\hline Mexico & 3 & 3 & 3 & 3 & 3 & 5 & 5 & 5 & 5 & 5 & 5 & 5 \\
\hline Netherlands & 1 & 1 & 1 & 1 & 1 & 1 & 4 & 4 & 4 & 4 & 4 & 4 \\
\hline Norway & 2 & 2 & 2 & 2 & 2 & 2 & 2 & 2 & 2 & 2 & 2 & 2 \\
\hline Peru & 0 & 0 & 0 & 0 & 0 & 4 & 4 & 4 & 4 & 4 & 5 & 5 \\
\hline Poland & 4 & 4 & 4 & 4 & 4 & 4 & 4 & 4 & 4 & 4 & 4 & 4 \\
\hline Portugal & 1 & 1 & 1 & 1 & 1 & 1 & 4 & 4 & 4 & 4 & 4 & 4 \\
\hline Romania & 2 & 2 & 2 & 2 & 2 & 2 & 2 & 2 & 2 & 2 & 2 & 3 \\
\hline Russia & 2 & 2 & 2 & 2 & 2 & 2 & 2 & 2 & 2 & 2 & 2 & 2 \\
\hline Slovak Republic & 2 & 2 & 2 & 2 & 2 & 2 & 2 & 2 & 2 & 2 & 2 & 2 \\
\hline Slovenia & 4 & 4 & 4 & 4 & 4 & 4 & 4 & 4 & 4 & 4 & 4 & 4 \\
\hline Spain & 2 & 2 & 2 & 2 & 2 & 2 & 2 & 2 & 2 & 2 & 2 & 3 \\
\hline Sweden & 2 & 2 & 2 & 2 & 2 & 2 & 2 & 2 & 2 & 2 & 2 & 3 \\
\hline Switzerland & 2 & 2 & 2 & 2 & 2 & 2 & 2 & 2 & 2 & 2 & 2 & 2 \\
\hline Thailand & 2 & 2 & 2 & 2 & 2 & 2 & 2 & 2 & 2 & 2 & 2 & 2 \\
\hline United Kingdom & 3 & 3 & 3 & 3 & 3 & 3 & 3 & 3 & 3 & 3 & 3 & 3 \\
\hline United States & 4 & 4 & 4 & 4 & 4 & 4 & 4 & 4 & 4 & 4 & 4 & 4 \\
\hline
\end{tabular}

Source: Lohse et al. (2012). Classification of transfer-pricing regulation from 0 (no transfer-regulations) to 5 (very strict transfer-pricing regulation). 


\section{A.2 References}

Ambrosanio, M.F. and M.S. Caroppo (2005), Eliminating harmful tax practices in tax havens: defensive measures by major EU countries and tax haven reforms, Canadian Tax Journal 53, 685-719.

Bartelsman, E.J., and R.M.W.J. Beetsma, 2003, Why pay more? Corporate tax avoidance through transfer pricing in OECD countries, Journal of Public Economics, 87(9-10), 2225-2252.

Becker, J., and C. Fuest (2012), Transfer pricing policy and the intensity of tax rate competition, Economics Letters, 117 (1), 146-148.

Beuselinck, C., M. Deloof and A. Vanstraelen (2009), Multinational income shifting, tax enforcement and firm value, Working Paper, Tilburg University.

Blouin, J.L., L.A. Robinson and J. Seidman (2010), Transfer pricing behaviour in a world of multiple taxes, Tuck School of Business Working Paper 2010-74, Dartmouth.

Bucovetsky, S. and A. Haufler (2008), Tax competition when firms choose their organizational form: should tax loopholes for multinationals be closed? Journal of International Economics 74, 188-201.

Buettner, T., M. Overesch, U. Schreiber, and G. Wamser (2012), The impact of thin-capitalization rules on the capital structure of multinational firms, Journal of Public Economics 96, 930-938.

Buettner and Wamser (2013), Internal debt and multinationals' profit shifting - empirical evidence from firm-level panel data, National Tax Journal 66, 63-95.

Clausing, K.A. (2003), Tax-motivated transfer pricing and US intrafirm trade, Journal of Public Economics 87, 2207-2223.

De Mooij, R.A. and S. Ederveen (2003), Taxation and foreign direct investment: a synthesis of empirical research, International Tax and Public Finance 10, 673-693.

De Mooij, R.A. and S. Ederveen (2008), Corporate tax elasticities: a reader's guide to empirical findings, Oxford Review of Economic Policy 24 (4), 680-697.

Desai, M.A., C.F. Foley and J.R. Hines (2004), A multinational perspective on capital structure choice and internal capital markets, Journal of Finance 59, 2451-2487.

Dischinger, M. and N. Riedel (2011), Corporate taxes, profit shifting and the location of intangibles within multinational firms, Journal of Public Economics 95, 691-707.

Dourado, A.P. and R. de la Feria (2008), Thin capitalization rules in the context of the CCCTB, Oxford University Centre for Business Taxation Working Paper Series, WP 08/04.

Durst, M.C. and R.E. Culbertson (2003), Clearing away the sand: retrospective methods and prospective documentation in transfer pricing today, Tax Law Review 57, 37-134.

European Commission (1997), A package to tackle harmful tax competition in the European Union, $\operatorname{COM}(97) 564$ final. 
Feld, L. and J.H. Heckemeyer (2011), FDI and taxation: a meta-study. Journal of Economic Surveys, 25, 233-272.

Grubert, H. (2003), Intangible income intercompany transactions, income shifting, and the choice of location, National Tax Journal 56, 221-242.

Harris, D.G. (1993), The impact of U.S. tax law revision on multinational corporations' capital location and income shifting decisions, Journal of Accounting Research (Supplement) 31, 111-140.

Haufler, A. and M. Runkel (2012), Firms' financial choices and thin capitalization rules under corporate tax competition, European Economic Review 56, 1087-1103.

Hong, Q. and M. Smart (2010), In praise of tax havens: international tax planning and foreign direct investment, European Economic Review, 54, 82-95.

Huizinga, H., L. Laeven and G. Nicodème (2008), Capital structure and international debt shifting, Journal of Financial Economics 88, 80-118.

Janeba, E. (1995), Corporate income tax competition, double taxation treaties, and foreign direct investment, Journal of Public Economics 56, 311-325.

Janeba, E. and M. Smart (2003), Is targeted tax competition less harmful than its remedies? International Tax and Public Finance 10, 259-280.

Jost, S.P., M. Pfaffermayer and H. Winner (2010), Transfer pricing as a tax compliance risk, Working Paper 2010-06, University of Salzburg.

Keen, M. (2001), Preferential regimes can make tax competition less harmful, National Tax Journal 54, 757-762.

Lohse,T., N. Riedel and C. Spengel (2012), The increasing importance of transfer pricing regulations a worldwide overview, Oxford University Centre for Business Taxation Working Paper Series, WP 12/27.

Lipponer, A. (2006), Microdatabase direct investment - MiDi. A brief guide, Bundesbank Working Paper, Frankfurt.

Mintz, J. and M. Smart (2004), Income shifting, investment, and tax competition: theory and evidence from provincial taxation in Canada, Journal of Public Economics 88, 1149-1168.

Mintz, J. and A.J. Weichenrieder (2010), The indirect side of direct investment - multinational company finance and taxation, MIT Press.

OECD (1987), Thin-capitalization and taxation of entertainers, artistes and sportsmen, Comittee on Fiscal Affairs, Issues in International Taxation No. 2, Paris.

OECD (1998), Harmful tax competition: an emerging global issue, Paris.

OECD (2010), Transfer pricing guidelines for multinational enterprises and tax administrations, Paris. 
OECD (2013), Action plan on base erosion and profit shifting, Paris.

Overesch, M. and G. Wamser (2010), Corporate tax planning and thin-capitalization rules: evidence from a quasi-experiment, Applied Economics 42, 563-573.

Peralta, S., X. Wauthy and T. van Ypersele (2006), Should countries control international profit shifting? Journal of International Economics 68, 24-37.

Piltz, D. (1996), General report, Cahiers de Droit Fiscal LXXXIb, 83-140.

Slemrod, J., and J. D. Wilson (2009), Tax competition with parasitic tax havens, Journal of Public Economics, 93 (11-12), 1261-1270.

Swenson, D.L. (2001), Tax reforms and evidence of transfer pricing, National Tax Journal 54, $7-25$.

Wamser, G. (2011), Foreign (in)direct investment and corporate taxation, Canadian Journal of Economics, 44, 1497-1524.

Wamser, G. (2013), The impact of thin-capitalization rules on external debt usage - a propensity score matching approach, Oxford Bulletin of Economics $\& 5$ Statistics, forthcoming.

Weichenrieder, A.J., and H. Windischbauer (2008), Thin-capitalization rules and company responses - experience from German legislation, CESifo Working Paper 2456, Munich. 